Check for updates

Cite this: RSC Adv., 2018, 8, 22250

Received 14th May 2018

Accepted 11th June 2018

DOI: $10.1039 / c 8 r a 04077 j$

rsc.li/rsc-advances

\title{
Tubular and lamellar hydrogen-bonding molecular assemblies of isophthalic acid derivatives bearing a $-\mathrm{CONHC}_{n} \mathrm{H}_{2 n+1}$ chain $\uparrow$
}

\author{
Chao Lv, ${ }^{\text {ac }}$ Takashi Takeda, (D) *ab Norihisa Hoshino ${ }^{\text {ab }}$ and Tomoyuki Akutagawa (D) *ab
}

Isophthalic acid derivatives (CnIP), bearing alkylamide chains ( $-\mathrm{CONHC}_{n} \mathrm{H}_{2 n+1}: n=6,10,14$, and 18) at the 5 -position that can participate in hydrogen bonding, were prepared and evaluated for their hydrogenbonding molecular assembly structures for organogelation and liquid crystal formation. The hydrogenbonding carboxylic acid $(-\mathrm{COOH})$ groups form a ring-shaped $(\mathrm{CnIP})_{6}$ hexamer or a one-dimensional (1D) zig-zag $(\mathrm{CnIP})_{\infty}$ chain. Although neither organogelation nor liquid crystal formation was observed in the isophthalic acid derivative bearing an alkoxy $\left(-\mathrm{OC}_{14} \mathrm{H}_{29}\right)$ chain, C14IP and C18IP derivatives could form both organogel and liquid crystal states through intermolecular $\mathrm{N}-\mathrm{H} \cdots \mathrm{O}=$ amide-type hydrogenbonding interactions. A discotic hexagonal columnar liquid crystal $\left(\mathrm{Col}_{h}\right)$ phase was observed in hydrated $(\mathrm{C} 14 \mathrm{IP})_{6} \cdot\left(\mathrm{H}_{2} \mathrm{O}\right)_{n}$ and $(\mathrm{C} 18 \mathrm{IP})_{6} \cdot\left(\mathrm{H}_{2} \mathrm{O}\right)_{n}$, whereas a lamella-type liquid crystal $\left(\mathrm{L}_{a}\right)$ phase was confirmed in the unhydrated C18IP. In the $\mathrm{Col}_{\mathrm{h}}$ phase, $\mathrm{O}-\mathrm{H} \cdots \mathrm{O}$ hydrogen-bonding ring-shaped $(\mathrm{C} 14 \mathrm{IP})_{6}$ and $(\mathrm{C} 18 \mathrm{IP})_{6}$ hexamers assembled to form the tubular molecular assembly stabilized by intermolecular $-\mathrm{N}-\mathrm{H} \cdots \mathrm{O}=$ hydrogen-bonding interactions along the tube growth direction, where $\mathrm{H}_{2} \mathrm{O}$ molecules were contained within the hydrophilic space. On the other hand, the $\mathrm{N}-\mathrm{H} \cdots \mathrm{O}=$ hydrogen-bonding interactions between the $1 \mathrm{D}$ zig-zag $(\mathrm{CnIP})_{\infty}$ chains formed a layer-type molecular assembly of the $\mathrm{L}_{\mathrm{a}}$-phase in the absence of water molecules.

\section{Introduction}

Amide-type $\mathrm{N}-\mathrm{H} \cdots \mathrm{O}=$ hydrogen-bonding in polypeptide chains plays an important role in forming the secondary protein structures of $\alpha$-helices and $\beta$-sheets, which are further assembled to form ternary protein structures through weak van der Waals interactions. ${ }^{1}$ The bonding energy of the amide-type hydrogenbinding interaction is approximately $10 \mathrm{~kJ} \mathrm{~mol}^{-1}$, a magnitude favourable for achieving association/dissociation of secondary protein structures at approximately room temperature $\left(k_{\mathrm{B}} T \approx\right.$ $\left.2.5 \mathrm{~kJ} \mathrm{~mol}^{-1}\right) \cdot{ }^{2-5}$ Therefore, amide-type $\mathrm{N}-\mathrm{H} \cdots \mathrm{O}=$ hydrogenbonding interaction is a key intermolecular interaction that controls hierarchical molecular assembly structures. In the field of supramolecular chemistry, directional hydrogen bonding has been used for the construction of various anisotropic molecular assemblies from one-dimensional (1D) chains of phthalic or isophthalic acids, ${ }^{6-8}$ two-dimensional (2D) layers of squaric or

${ }^{a}$ Graduate School of Engineering, Tohoku University, Sendai 980-8579, Japan

${ }^{b}$ Institute of Multidisciplinary Research for Advanced Materials (IMRAM), Tohoku University, 2-1-1 Katahira, Aoba-ku, Sendai 980-8577, Japan. E-mail: akutagawa@ tohoku.ac.jp; Tel: $+81-22-217-5653$

'Institute of Materials, China Academy of Engineering Physics, Jiangyou 621908, Sichuan, P. R. China

$\dagger$ Electronic supplementary information (ESI) available: Experimental section, OG states, SEM images, TG and DSC charts, XRD patterns, vibrational spectra, and elemental analyses. See DOI: 10.1039/c8ra04077j trimesic acids, , $^{\mathbf{9} 10}$ and three-dimensional (3D) diamond-like networks of tetracarboxylic acid derivatives. ${ }^{11,12}$ Among a variety of directional hydrogen-bonding interactions such as $\mathrm{O}-\mathrm{H} \cdots \mathrm{O}, \mathrm{N}-$ $\mathrm{H} \cdots \mathrm{O}$, and $\mathrm{N}-\mathrm{H} \cdots \mathrm{N}$, amide-type $\mathrm{N}-\mathrm{H} \cdots \mathrm{O}=$ hydrogen-bonding has been used to design single crystal organic ferroelectrics ${ }^{13-17}$ and discotic hexagonal columnar liquid crystal $\left(\mathrm{Col}_{h}\right)$ phases of benzene derivatives bearing multiple alkylamide $\left(-\mathrm{CONHC}_{n} \mathrm{H}_{2 n+1}\right)$ chains. ${ }^{18-22}$ For instance, ferroelectric polarization $(P)$-electric field (E) hysteresis curves have been observed for $N, N^{\prime}, N^{\prime \prime}$-trialkyl-1,3,5benzenetricarboxamide (3BC) derivatives; a response is achieved by collective inversion of the $1 \mathrm{D} \mathrm{N}-\mathrm{H} \cdots \mathrm{O}=$ hydrogen-bonding interactions along the $\pi$-stacking column. ${ }^{18-22}$ The application of the opposite $E$-value along the hydrogen-bonding column inverts the direction of the macro dipole moment arising from the $(\mathrm{N}-\mathrm{H} \cdots$ $\mathrm{O}=)_{\infty}$ chains via rotation of the $-\mathrm{CONHC}_{n} \mathrm{H}_{2 n+1}$ groups in $\mathrm{Col}_{\mathrm{h}}$ phase. In addition, derivatives of $N, N^{\prime}$-ditetradecyl-1,4benzenedicarboxamide (2BC) and $N, N^{\prime}, N^{\prime \prime}, N^{\prime \prime \prime}, N^{\prime \prime \prime \prime}$ pentatetradecyl-1,2,3,4,5-benzenepentacarboxamide (5BC) were used to prepare ferroelectrics. ${ }^{22}$ Interestingly, a $\mathrm{Col}_{\mathrm{h}}$ liquid crystalline material composed of $N, N^{\prime}, N^{\prime \prime}, N^{\prime \prime \prime}$-tetratetradecyl-1,3,6,8pyrenetetracarboxamide also formed a ferroelectric material with fluorescent and current switching properties. ${ }^{23,24}$ The $1 \mathrm{D}$ hydrogenbonding molecular assembly and its dynamic behaviour are essential to the ferroelectric behaviour of the $\pi$-molecular system bearing multiple $-\mathrm{CONHC}_{n} \mathrm{H}_{2 n+1}$ chains. Improved design of amide-type hydrogen-bonding has the potential to form low- 
dimensional hierarchical molecular assemblies such as rings, tubes, chains, and layer structures.

Additional hydrogen-bonding sites such as $-\mathrm{OH},-\mathrm{NH}_{2}$, and $-\mathrm{COOH}$ are usually introduced into molecular structures to form the low-dimensional molecular assemblies. ${ }^{25-29}$ Wellknown hydrogen-bonding simple benzene carboxylic acid derivatives of trimesic acid can form two types of $\mathrm{O}-\mathrm{H} \cdots \mathrm{O}=$ hydrogen-bonding molecular assemblies: a six-fold 2D hexagonal layer and an infinite 1D zig-zag chain, which can be controlled by crystallization conditions. On the other hand, terephthalic and isophthalic acids typically form 1D linear and 1D zig-zag type $\mathrm{O}-\mathrm{H} \cdots \mathrm{O}=$ hydrogen-bonding molecular assemblies, respectively ${ }^{6-8}$ It can be reasonably expected that these benzene carboxylic acid derivatives can act as effective platforms to construct various molecular assemblies in a flexible and rational way by introducing additional hydrogenbonding group. For instance, an interesting ring-shaped molecular assembly was reported using an isophthalic acid (IP) derivative bearing a hydrophobic $-\mathrm{OC}_{n} \mathrm{H}_{2 n+1}$ chain at the 5position, which formed a hydrogen-bonding $\mathrm{O}-\mathrm{H} \cdots \mathrm{O}=$ hexamer structure at $n<12$, and each hexamer ring was isolated in the absence of interactions between the hexamers. ${ }^{30-32}$ In contrast, 1D zig-zag hydrogen-bonding structures have been observed in long alkyl chain compounds with $n>12$, where the much longer alkyl chains enhanced hydrophobic interactions and stabilized the interdigitate lamellar-type molecular assembly structure. Although interesting ring-shaped hydrogenbonding hexamer assemblies have been obtained by introducing alkoxy group into IP derivative, additional introduction of amide-type $\mathrm{N}-\mathrm{H} \cdots \mathrm{O}=$ hydrogen-bonding interaction at $-\mathrm{CONHC}_{n} \mathrm{H}_{2 n+1}$ chain has a potential to form various kinds of low-dimensional hierarchical molecular assembly structures.

Herein, we designed a hydrogen-bonding IP derivative bearing an additional hydrogen-bonding $-\mathrm{CONHC}_{n} \mathrm{H}_{2 n+1}$ chain to achieve low-dimensional molecular assemblies, which will fabricate different types of molecular assemblies from $-\mathrm{OC}_{n} \mathrm{H}_{2 n+1}$ substituted IP derivative. Four kinds of amphiphilic IP derivatives bearing a different alkyl chain length of $-\mathrm{CONHC}_{n} \mathrm{H}_{2 n+1}, \operatorname{C6IP}(n=6), \operatorname{C10IP}(n=10), \operatorname{C14IP}(n=14)$, and C18IP $(n=18)$, were synthesized and corresponding molecular assembly behaviours were studied systematically. Different from the IP derivative with an $-\mathrm{OC}_{n} \mathrm{H}_{2 n+1}$ chain, the hydrogen-bonding $-\mathrm{CONHC}_{n} \mathrm{H}_{2 n+1}$ chain in CnIP can provide additional $-\mathrm{N}-\mathrm{H} \cdots \mathrm{O}=$ hydrogen-bonding interactions to form high-order molecular assembly structures (Scheme 1). The $\mathrm{O}-\mathrm{H} \cdots \mathrm{O}=$ hydrogen-bonding ring-hexamers are connected by six amide-type $\mathrm{N}-\mathrm{H} \cdots \mathrm{O}=$ hydrogen-bonding interactions along the $\pi$-stacking direction of the hexamer, resulting in a tubular hierarchical molecular assembly with an inner pore diameter of $\sim 1.1 \mathrm{~nm}$. Since the outer surface and inner pore of the tubular assembly are hydrophobic and hydrophilic, respectively, the inner hydrophilic pore can capture hydrophilic species such as $\mathrm{H}_{2} \mathrm{O}$ and various ions. Another possible molecular assembly is a zig-zag type $\mathrm{O}-\mathrm{H} \cdots \mathrm{O}$ hydrogen-bonding $1 \mathrm{D}$ assembly, which are connected by amide-type $\mathrm{N}-\mathrm{H} \cdots \mathrm{O}=$ hydrogen-bonding interactions along the direction normal to the $1 \mathrm{D}$ chain. These chains are formed in a similar manner as the lamellar-

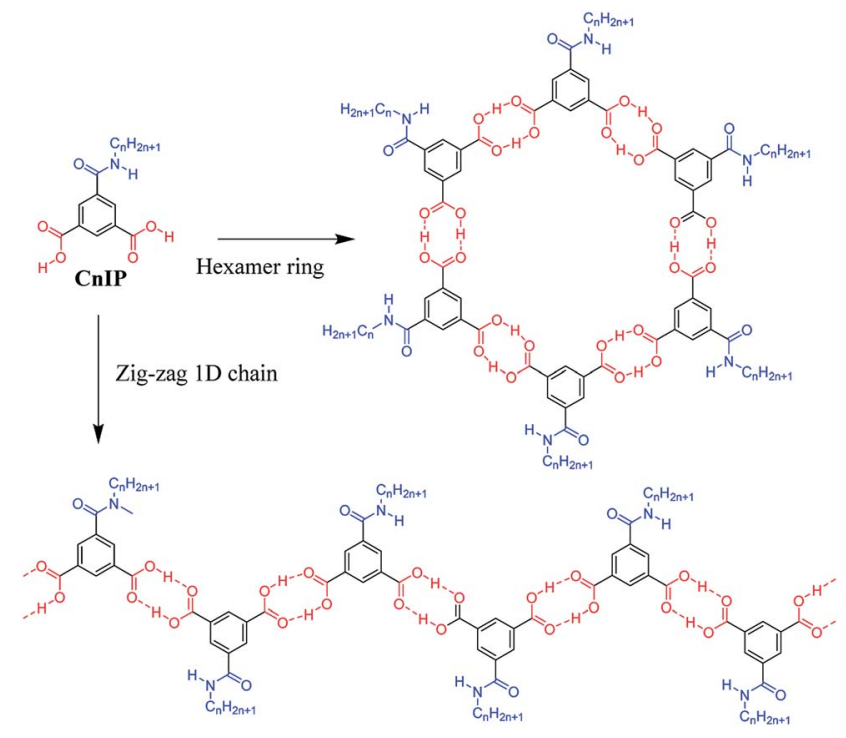

Scheme 1 Two kinds of primary hydrogen-bonding interactions (red $\mathrm{O}-\mathrm{H} \cdots \mathrm{O}$ interaction) to form the ring-hexamer $(\mathrm{CnIP})_{6}$ and the zigzag $1 \mathrm{D}$ chain $(\mathrm{CnIP})_{\infty}$. The diameter of the inner pore is approximately $1.1 \mathrm{~nm}$ for the hexamer $(\mathrm{CnIP})_{6}$. Further secondary $\mathrm{N}-\mathrm{H} \cdots \mathrm{O}=$ hydrogen-bonding interactions (blue $\mathrm{N}-\mathrm{H} \cdots \mathrm{O}=$ ) assembled each hexamer and/or chain to form tubular and lamellar type molecular assemblies, respectively.

type 2D molecular assembly structure with alternating arrangement of the hydrogen-bonding layer and hydrophobic alkyl chains. Accordingly, both organogel and liquid crystal states were formed in the assembly system via additional intermolecular $\mathrm{N}-\mathrm{H} \cdots \mathrm{O}=$ amide-type hydrogen-bonding interactions in a prime IP molecular core. Moreover, the liquid crystalline phase was modulated by the gelation process of C18IP. Pure unhydrated state formed the lamellar type liquid crystalline phase, whereas the xerogel state of $(\mathbf{C 1 8 I P})_{6} \cdot\left(\mathrm{H}_{2} \mathrm{O}\right)_{n}$ from $\mathrm{C}_{2} \mathrm{H}_{5} \mathrm{OH}-\mathrm{H}_{2} \mathrm{O}$ formed the tubular structure and hexagonal columnar liquid crystalline phase. The gelation ability was directly associated with the formation of lamellar and/or hexagonal columnar phases. The thermal stability, organogelation ability, liquid crystal formation, phase transition behaviour, and ion inclusion properties of the prepared assemblies were systematically examined.

\section{Experimental section}

\section{Preparation of CnIP}

Commercially available reagents were used without further purification, and dry triethylamine was obtained by distillation from $\mathrm{KOH}$. The preparation of $\operatorname{CnIP}(n=6,10,14$, and 18) was performed by a 4-step procedure starting from 1,3,5-benzenetricarboxylic acid trimethyl ester (Scheme 2). Benzene-1,3,5tricarboxylic acid dimethyl ester was prepared following the

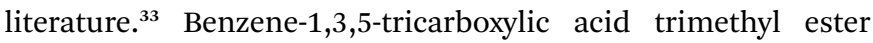
(5.00 g, $7.93 \mathrm{mmol}$ ) and $\mathrm{NaOH}(790 \mathrm{mg}, 19.8 \mathrm{mmol}$ ) were dissolved in $\mathrm{CH}_{3} \mathrm{OH}(175 \mathrm{~mL})$ and refluxed for $12 \mathrm{~h}$. The reaction mixture was diluted with water $(500 \mathrm{~mL})$, and washed with 

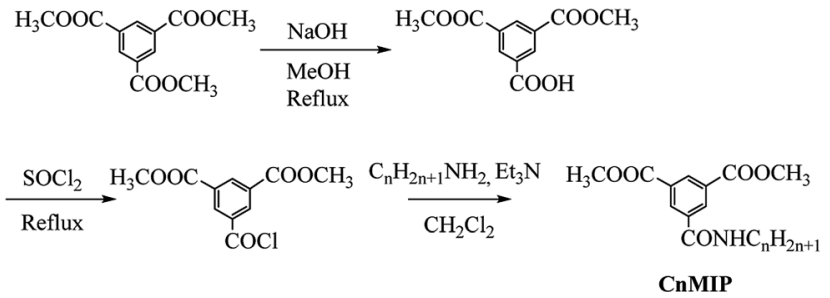

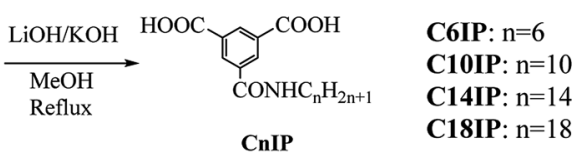

Scheme 2 Synthetic procedure for the CnIP derivatives.

diethyl ether $(3 \times 250 \mathrm{~mL})$. The aqueous phase was acidified to $\mathrm{pH} \sim 1$ with $5 \%$ hydrochloric acid and extracted with diethyl ether $(3 \times 250 \mathrm{~mL})$. The extracted organic layers were dried over $\mathrm{MgSO}_{4}$ and concentrated under vacuum to afford benzene1,3,5-tricarboxylic acid dimethyl ester(3.83 g) with a yield of 81\%. ${ }^{1} \mathrm{H}$ NMR (400 MHz, DMSO- $d_{6}$ ): 8.60-8.65 (m, 3H, Ar-H), $3.93\left(\mathrm{~s}, 6 \mathrm{H},-\mathrm{OCH}_{3}\right)$.

\section{C6IP}

Benzene-1,3,5-tricarboxylic acid dimethyl ester $(2.10 \mathrm{~g}, 8.81$ $\mathrm{mmol})$ in $\mathrm{SOCl}_{2}(80 \mathrm{~mL}, 1.10 \mathrm{~mol})$ was refluxed for $20 \mathrm{~h}$. After cooling the reaction mixture to room temperature, the excess $\mathrm{SOCl}_{2}$ was removed under vacuum. The resultant acid chloride was dissolved in dry $\mathrm{CH}_{2} \mathrm{Cl}_{2}(40 \mathrm{~mL})$, and hexylamine $(1.32 \mathrm{~mL}$, $10.1 \mathrm{mmol}$ ) was slowly added dropwise over $10 \mathrm{~min}$ followed by the addition of triethylamine $(1.28 \mathrm{~mL}, 9.24 \mathrm{mmol})$. The mixture was subsequently stirred for $18 \mathrm{~h}$ at room temperature. The resultant solution was washed 3 times with aqueous $1 \mathrm{M} \mathrm{HCl}$ and brine, and then dried over $\mathrm{Na}_{2} \mathrm{SO}_{4}$. Evaporation of $\mathrm{CH}_{2} \mathrm{Cl}_{2}$ under reduced pressure yielded a white precipitate, which was recrystallized from hexane : AcOEt $(2: 5)$. A total of $1.52 \mathrm{~g}$ of $N$ hexyl-3,5-bis(methoxylcarbonyl)benzamide (C6MIP) was obtained with a yield of $56 \% .{ }^{1} \mathrm{H} \mathrm{NMR}\left(400 \mathrm{MHz}, \mathrm{CDCl}_{3}\right): \delta 0.90(\mathrm{t}, J$ $\left.=7.1 \mathrm{~Hz}, 3 \mathrm{H},-\mathrm{CH}_{3}\right), 1.30-1.45(\mathrm{~m}, 6 \mathrm{H}$, alkyl $), 1.62-1.69(\mathrm{~m}, 2 \mathrm{H}$, $-\mathrm{NHCH}_{2} \mathrm{CH}_{2}$ ), 3.45-3.52 (m, 2H, $-\mathrm{NHCH}_{2} \mathrm{CH}_{2}$ ), 3.98 (s, 6H, 2Ar$\left.\mathrm{COOCH}_{3}\right), 6.26(\mathrm{~s}, 1 \mathrm{H}, \mathrm{NH}), 8.61(\mathrm{~d}, J=1.6 \mathrm{~Hz}, 2 \mathrm{H}, \mathrm{ArH}), 8.80(\mathrm{t}$, $J=1.6 \mathrm{~Hz}, 1 \mathrm{H}, \mathrm{ArH})$.

A solution of C6MIP $(1.52 \mathrm{~g}, 4.73 \mathrm{mmol})$ in $\mathrm{CH}_{3} \mathrm{OH}(25 \mathrm{~mL})$ was added to a solution of $\mathrm{KOH}(2.91 \mathrm{~g}, 51.8 \mathrm{mmol})$ in water (20 $\mathrm{mL}$ ), and the resulting solution was refluxed for $2 \mathrm{~h}$. After evaporation of $\mathrm{CH}_{3} \mathrm{OH}$ under vacuum, the reaction mixture was diluted with $\mathrm{H}_{2} \mathrm{O}(300 \mathrm{~mL})$ and aqueous $\mathrm{HCl}(1 \mathrm{M})$ until the $\mathrm{pH}$ reached 1 . The resulting suspension was extracted by AcOEt and dried over $\mathrm{Na}_{2} \mathrm{SO}_{4}$. Removal of solvent under vacuum afforded a crude product, which was recrystallized twice from $\mathrm{CH}_{3}$ $\mathrm{OH}: \mathrm{H}_{2} \mathrm{O}(4: 1)$ to give $\mathbf{C 6 I P}(880 \mathrm{mg})$ with a yield of $63 \% . \mathrm{Mp}=$ 279-280 ${ }^{\circ}$ C. ${ }^{1} \mathrm{H}$ NMR (400 MHz, DMSO- $\left.d_{6}\right): 0.87(\mathrm{t}, J=6.8 \mathrm{~Hz}, 3 \mathrm{H}$, $\left.-\mathrm{CH}_{3}\right), 1.23-1.36\left(\mathrm{~m}, 6 \mathrm{H}\right.$, alkyl), 1.48-1.58 (m, 2H, $-\mathrm{NHCH}_{2} \mathrm{CH}_{2}$ ), $3.23-3.31\left(\mathrm{~m}, 2 \mathrm{H},-\mathrm{NHCH}_{2}\right), 8.56(\mathrm{t}, J=1.6 \mathrm{~Hz}, 1 \mathrm{H}, \mathrm{ArH}), 8.63(\mathrm{~d}, J$ $=1.6 \mathrm{~Hz}, 2 \mathrm{H}, \operatorname{ArH}), 8.88(\mathrm{t}, J=5.6 \mathrm{~Hz}, 1 \mathrm{H},-\mathrm{NH}), 13.50(\mathrm{~s}, 2 \mathrm{H}$, $-(\mathrm{C}=\mathrm{O})-\mathrm{OH})$. IR: $\nu\left(\mathrm{cm}^{-1}\right): 3287(\mathrm{~N}-\mathrm{H}$ stretch $), 1688(\mathrm{C}=\mathrm{O}$ of $\mathrm{COOH}), 1634(\mathrm{C}=\mathrm{O}$ of $\mathrm{CONH}), 1544(\mathrm{C}-\mathrm{N})$. Elemental analysis: calculated for $\mathrm{C}_{15} \mathrm{H}_{19} \mathrm{NO}_{5}$ : C, 61.42; $\mathrm{H}, 6.53 ; \mathrm{N}, 4.78$. Found: $\mathrm{C}$,
61.25; $\mathrm{H}, 6.64 ; \mathrm{N}, 4.82$. High resolution mass spectrometry (HRMS) fast atom bombardment (FAB): calculated for $\mathrm{C}_{15} \mathrm{H}_{20} \mathrm{NO}_{5}$ $m / z 294.1341\left[(\mathrm{M}+\mathrm{H})^{+}\right]$, found $m / z$ 294.1339.

Preparations of C10IP, C14IP, and C18IP were performed by the similar procedure to that of C6IP using the corresponding alkylamines (see the ESI $\uparrow$ for detail).

C10MIP. Yield $928 \mathrm{mg}, 29 \% .{ }^{1} \mathrm{H}$ NMR (400 $\mathrm{MHz}, \mathrm{CDCl}_{3}$ ): $\delta 0.88\left(\mathrm{t}, J=6.8 \mathrm{~Hz}, 3 \mathrm{H},-\mathrm{CH}_{3}\right), 1.20-1.45$ (m, 14H, alkyl), 1.58$1.69\left(\mathrm{~m}, 2 \mathrm{H},-\mathrm{NHCH}_{2} \mathrm{CH}_{2}\right), 3.45-3.52\left(\mathrm{~m}, 2 \mathrm{H},-\mathrm{NHCH}_{2} \mathrm{CH}_{2}\right)$, $3.98\left(\mathrm{~s}, 6 \mathrm{H}, 2 \mathrm{Ar}-\mathrm{COOCH}_{3}\right), 6.22(\mathrm{br} \mathrm{s}, 1 \mathrm{H}, \mathrm{NH}), 8.61$ (d, $J=$ $1.6 \mathrm{~Hz}, 2 \mathrm{H}, \mathrm{ArH}), 8.79(\mathrm{t}, J=1.6 \mathrm{~Hz}, 1 \mathrm{H}, \mathrm{ArH})$.

C10IP. Yield $760 \mathrm{mg}, 63 \% . \mathrm{Mp}=245-246{ }^{\circ} \mathrm{C} .{ }^{1} \mathrm{H}$ NMR $(400$ $\left.\mathrm{MHz}, \mathrm{DMSO}-d_{6}\right): \delta 0.84\left(\mathrm{t}, J=6.8 \mathrm{~Hz}, 3 \mathrm{H},-\mathrm{CH}_{3}\right), 1.16-1.35(\mathrm{~m}$, $14 \mathrm{H}$, alkyl), $1.48-1.59$ (t, $J=6.8 \mathrm{~Hz}, 2 \mathrm{H},-\mathrm{NHCH}_{2} \mathrm{CH}_{2}$ ), 3.27 (q, $J$ $\left.=6.5 \mathrm{~Hz}, 2 \mathrm{H},-\mathrm{NHCH}_{2}\right), 8.56(\mathrm{t}, J=1.6 \mathrm{~Hz}, 1 \mathrm{H}, \mathrm{ArH}), 8.63(\mathrm{t}, J=$ $1.6 \mathrm{~Hz}, 2 \mathrm{H}, \mathrm{ArH}), 8.87(\mathrm{t}, J=5.2 \mathrm{~Hz}, 1 \mathrm{H},-\mathrm{NH}), 13.50(\mathrm{~s}, 2 \mathrm{H}$, $-(\mathrm{C}=\mathrm{O})-\mathrm{OH})$. IR: $\nu\left(\mathrm{cm}^{-1}\right): 3300(\mathrm{~N}-\mathrm{H}$ stretch), 1720 and 1695 $(\mathrm{C}=\mathrm{O}$ of $\mathrm{COOH}, \mathrm{C}=\mathrm{O}$ stretching vibration of the free, nonhydrogen bonded and laterally hydrogen-bonded $\mathrm{COOH}$ groups, respectively), $1640(\mathrm{C}=\mathrm{O}$ of $\mathrm{CONH}), 1544$ (C-N). Elemental analysis: calculated for $\mathrm{C}_{19} \mathrm{H}_{27} \mathrm{NO}_{5}$ : C, 65.31; $\mathrm{H}$, 7.79; N, 4.01. Found: C, 65.28; H, 7.91; N, 4.00. HRMS (FAB): calculated for $\mathrm{C}_{19} \mathrm{H}_{28} \mathrm{NO}_{5} \mathrm{~m} / z 350.1967\left[(\mathrm{M}+\mathrm{H})^{+}\right]$, found $\mathrm{m} / \mathrm{z}$ 350.1972 .

C14MIP. Yield $1.08 \mathrm{~g}, 73 \% .{ }^{1} \mathrm{H}$ NMR (400 MHz, $\left.\mathrm{CDCl}_{3}\right): \delta 0.88$ $\left(\mathrm{t}, J=6.4 \mathrm{~Hz}, 3 \mathrm{H}, \mathrm{CH}_{3}\right), 1.21-1.44(\mathrm{~m}, 22 \mathrm{H}$, alkyl), 1.59-1.69 (m, $\left.2 \mathrm{H},-\mathrm{NHCH}_{2} \mathrm{CH}_{2}\right), 3.44-3.53\left(\mathrm{~m}, 2 \mathrm{H},-\mathrm{NHCH}_{2} \mathrm{CH}_{2}\right), 3.98(\mathrm{~s}, 6 \mathrm{H}$, $\left.2 \mathrm{Ar}-\mathrm{COOCH}_{3}\right), 6.21$ (br s, $\left.1 \mathrm{H}, \mathrm{NH}\right), 8.61$ (d, $\left.J=1.6 \mathrm{~Hz}, 2 \mathrm{H}, \mathrm{ArH}\right)$, $8.79(\mathrm{t}, J=1.6 \mathrm{~Hz}, 1 \mathrm{H}, \mathrm{ArH})$.

C14IP. Yield $646 \mathrm{mg}, 64 \%$. Mp: decomposed at above $241{ }^{\circ} \mathrm{C}$. ${ }^{1} \mathrm{H}$ NMR (400 MHz, DMSO- $\left.d_{6}\right): \delta 0.85\left(\mathrm{t}, J=6.8 \mathrm{~Hz}, 3 \mathrm{H}, \mathrm{CH}_{3}\right.$ ), 1.18-1.35 (m, 22H, alkyl), 1.48-1.58 (m, 2H, $\left.\mathrm{CONHCH}_{2} \mathrm{CH}_{2}\right)$, $3.29\left(\mathrm{~m}, 2 \mathrm{H}, \mathrm{CONHCH}_{2}\right), 8.56(\mathrm{t}, J=1.6 \mathrm{~Hz}, 1 \mathrm{H}, \mathrm{ArH}), 8.62(\mathrm{~s}$, $2 \mathrm{H}, \mathrm{ArH}), 8.85$ (br t, $J=4.8 \mathrm{~Hz}, 1 \mathrm{H}, \mathrm{NH}), 13.47$ (br s, 2H, $(\mathrm{C}=\mathrm{O})-$ $\mathrm{OH})$. IR: $\nu\left(\mathrm{cm}^{-1}\right): 3300(\mathrm{~N}-\mathrm{H}$ stretch $), 1720$ and $1695(\mathrm{C}=\mathrm{O}$ of $\mathrm{COOH}, \mathrm{C}=\mathrm{O}$ stretching vibration of the free, non-hydrogen bonded and laterally hydrogen-bonded $\mathrm{CO}_{2} \mathrm{H}$ groups, respectively), 1637 ( $\mathrm{C}=\mathrm{O}$ of $\mathrm{CONH}), 1537(\mathrm{C}-\mathrm{N})$. Elemental analysis calculated for $\mathrm{C}_{23} \mathrm{H}_{35} \mathrm{NO}_{5}: \mathrm{C}, 68.12 ; \mathrm{H}, 8.70 ; \mathrm{N}, 3.45$, found: $\mathrm{C}$, 68.37; H, 8.96; N, 3.57. HRMS (FAB): calculated for $\mathrm{C}_{23} \mathrm{H}_{36} \mathrm{NO}_{5}$ $m / z 406.2593\left[(\mathrm{M}+\mathrm{H})^{+}\right]$, found $m / z$ 406.2594.

C18MIP. Yield $2.40 \mathrm{~g}, 58 \% .{ }^{1} \mathrm{H}$ NMR (400 MHz, $\mathrm{CDCl}_{3}$ ): $\delta 0.85$ $\left(\mathrm{t}, J=6.8 \mathrm{~Hz}, 3 \mathrm{H}, \mathrm{CH}_{3}\right), 1.21-1.44(\mathrm{~m}, 30 \mathrm{H}$, alkyl), $1.60-1.70(\mathrm{~m}$, $\left.2 \mathrm{H},-\mathrm{NHCH}_{2} \mathrm{CH}_{2}\right), 3.45-3.52\left(\mathrm{~m}, 2 \mathrm{H},-\mathrm{NHCH}_{2} \mathrm{CH}_{2}\right), 3.98(\mathrm{~s}, 6 \mathrm{H}$, $\left.2 \mathrm{Ar}-\mathrm{COOCH}_{3}\right), 6.22(\mathrm{~s}, 1 \mathrm{H}, \mathrm{NH}), 8.61(\mathrm{~d}, J=1.6 \mathrm{~Hz}, 2 \mathrm{H}, \mathrm{ArH})$, $8.80(\mathrm{t}, J=1.6 \mathrm{~Hz}, 1 \mathrm{H}, \mathrm{ArH})$.

C18IP. Yield $1.77 \mathrm{~g}, 83 \%$. Mp: decomposed at above $231{ }^{\circ} \mathrm{C}$. ${ }^{1} \mathrm{H}$ NMR (400 MHz, DMSO- $\left.d_{6}\right): \delta 0.85\left(\mathrm{t}, J=6.8 \mathrm{~Hz}, 3 \mathrm{H},-\mathrm{CH}_{3}\right)$, 1.17-1.35 (m, 30H, alkyl), 1.47-1.58 (m, 2H, - $\left.\mathrm{NHCH}_{2} \mathrm{CH}_{2}\right), 3.23-$ $3.29\left(\mathrm{~m}, 2 \mathrm{H},-\mathrm{NHCH}_{2}\right), 8.56(\mathrm{t}, J=1.6 \mathrm{~Hz}, 1 \mathrm{H}, \mathrm{ArH}), 8.63(\mathrm{~s}, 2 \mathrm{H}$, $\mathrm{ArH}), 8.87(\mathrm{t}, J=5.5 \mathrm{~Hz}, 1 \mathrm{H},-\mathrm{NH}), 13.47(\mathrm{br} \mathrm{s}, 2 \mathrm{H},-(\mathrm{C}=\mathrm{O})-\mathrm{OH})$. IR: $\nu\left(\mathrm{cm}^{-1}\right): 3303(\mathrm{~N}-\mathrm{H}$ stretch), 1720 and $1695(\mathrm{C}=\mathrm{O}$ of $\mathrm{COOH}$, $\mathrm{C}=\mathrm{O}$ stretching vibration of the free, non-hydrogen bonded and laterally hydrogen-bonded $\mathrm{CO}_{2} \mathrm{H}$ groups, respectively), 1637 $(\mathrm{C}=\mathrm{O}$ of $\mathrm{CONH}), 1537(\mathrm{C}-\mathrm{N})$. Elemental analysis: calculated for $\mathrm{C}_{27} \mathrm{H}_{43} \mathrm{NO}_{5}$ : C, 70.25; H, 9.39; N, 3.03. Found: C, 69.97; H, 
9.45; N, 3.15. HRMS (FAB): calculated for $\mathrm{C}_{27} \mathrm{H}_{44} \mathrm{NO}_{5} \mathrm{~m} / \mathrm{z}$ $462.3219\left[(\mathrm{M}+\mathrm{H})^{+}\right]$, found $m / z$ 462.3219.

\section{Preparation of organogels}

Temperature and solvent dependent gelation behaviors were examined following in the literature. ${ }^{34} \mathrm{~A}$ series of commonly used solvent such as $\mathrm{CH}_{3} \mathrm{OH}, \mathrm{C}_{2} \mathrm{H}_{5} \mathrm{OH}$, acetone, THF, $\mathrm{CH}_{3} \mathrm{CN}$, AcOEt, toluene, and $\mathrm{H}_{2} \mathrm{O}$ was screened for the organogel formation of CnIP. The gelation behavior was not confirmed in each pure solvent. After the screening in the mixed solvent system, the organogels of CnIP were observed in $\mathrm{C}_{2} \mathrm{H}_{5} \mathrm{OH}-\mathrm{H}_{2} \mathrm{O}$. CnIP in hot $\mathrm{C}_{2} \mathrm{H}_{5} \mathrm{OH}-\mathrm{H}_{2} \mathrm{O}$ with concentration of $10 \mathrm{mM}$ was gradually cooled down to room temperature, and the minimum volume percentage of $\mathrm{H}_{2} \mathrm{O}$ to induce the organogels at $10 \mathrm{mM}$ was summarized in Table 1.

\section{Physical measurements}

Infrared spectroscopy (IR; Thermo Fisher Scientific Nicolet 6700, 400-4000 $\mathrm{cm}^{-1}$ ) measurements were conducted with a resolution of $4 \mathrm{~cm}^{-1}$ using $\mathrm{KBr}$ pellets. Thermogravimetrydifferential thermal analyses (TG-DTA) were conducted using a thermal analysis station (Rigaku Thermo plus TG8120) with $\mathrm{Al}_{2} \mathrm{O}_{3}$ as a reference from 293 to $600 \mathrm{~K}$ with a heating rate of 5 $\mathrm{K} \mathrm{min}^{-1}$ under a nitrogen atmosphere. Temperature-dependent powder pattern X-ray diffraction (XRD) data were collected using a diffractometer (Rigaku Rint-Ultima III) with $\mathrm{Cu} \mathrm{K} \alpha(\lambda=$ $1.54187 \AA$ ) radiation. Scanning electron microscopy (SEM; JEOL JSEM-5400F) and atomic force microscopy (AFM; JEOL JSPM5200) were performed on highly ordered pyrolytic graphite (HOPG) and mica substrates, respectively. Acceleration voltages of 5 or $10 \mathrm{kV}$ under a vacuum of less than $10^{-4}$ Pa was used for the SEM measurements. Commercially available Si cantilevers with a force constant of $4.5 \mathrm{~N} \mathrm{~m}^{-1}$ were used for the AFM measurements.

Table 1 Formation of OG and LC states of CnIP derivatives at $n=6$, 10,14 , and 18

\begin{tabular}{|c|c|c|c|c|}
\hline & C6IP & C10IP & C14IP & C18IP \\
\hline Formation of $\mathrm{OG}^{a}$ & $f^{f}$ & $\bigcirc^{e}$ & $\bigcirc^{e}$ & $\bigcirc^{e}$ \\
\hline $\begin{array}{l}\mathrm{H}_{2} \mathrm{O}(\mathrm{v} / \mathrm{v} \%) \text { in } \\
10 \mathrm{mM}^{2} \text { solution }\end{array}$ & - & 50 & 40 & 30 \\
\hline Xerogels $^{c}$ & - & - & $\bigcirc^{e}$ & $\bigcirc^{e}$ \\
\hline $\mathrm{H}_{2} \mathrm{O}(\mathrm{wt} \%)$ of xerogel ${ }^{c}$ & - & - & $3.7-7.2 \%$ & $3.3-7.3 \%$ \\
\hline $\mathrm{H}_{2} \mathrm{O}(\mathrm{wt} \%) \%$ of crystal & 0.0 & 0.0 & 0.0 & 0.0 \\
\hline Type of LC phase ${ }^{d}$ & - & - & $\mathrm{Col}_{\mathrm{h}}$ & $\mathrm{Col}_{\mathrm{h}}$ and $\mathrm{L}_{\mathrm{a}}$ \\
\hline
\end{tabular}

${ }^{a} \mathrm{OG}$ formation was evaluated in a $10 \mathrm{mM}$ solution of CnIP in $\mathrm{C}_{2} \mathrm{H}_{5} \mathrm{OH}-$ $\mathrm{H}_{2} \mathrm{O}\left(\mathrm{v} / \mathrm{v}=\right.$ volume percentage of $\left.\mathrm{H}_{2} \mathrm{O}\right)$ at $300 \mathrm{~K} .{ }^{b}$ Volume percentage of $\mathrm{H}_{2} \mathrm{O}$ for OG formation of CnIP at $c a$. fixed concentration of $10 \mathrm{mM}$ in $\mathrm{C}_{2} \mathrm{H}_{5} \mathrm{OH} .{ }^{c}$ Xerogels were obtained by vacuum evaporation of the OG and the weight percentage of $\mathrm{H}_{2} \mathrm{O}$ was determined by TG analyses. ${ }^{d} \mathrm{LC}$ phases of $\mathrm{Col}_{\mathrm{h}}$ and $\mathrm{L}_{\mathrm{a}}$ were discotic hexagonal columnar and lamella phases, respectively. Solvent loss of the C10IP xerogel was not obtained in the vacuum drying process at room temperature, and OG state was transformed to a crystalline solid. ${ }^{e}$ The notation of " $\bigcirc$ "represented the formation of $O G$ or xerogel states at a fixed concentration of $10 \mathrm{mM}$ in $\mathrm{C}_{2} \mathrm{H}_{5} \mathrm{OH}-\mathrm{H}_{2} \mathrm{O} .{ }^{f}$ OG states were not observed in $\mathrm{C}_{2} \mathrm{H}_{5} \mathrm{OH}-\mathrm{H}_{2} \mathrm{O}$ at v/v range from $100 / 0$ to $0 / 100$.

\section{Results and discussion}

\section{Formation of organogels}

The CnIP molecules $(n=6,10,14$, and 18) possess two kinds of hydrogen-bonding sites; two hydrophilic $-\mathrm{COOH}$ groups and one hydrophobic $-\mathrm{CONHC}_{n} \mathrm{H}_{2 n+1}$ chain, resulting in amphiphilic properties. The hydrophobic character of the CnIP derivatives was enhanced with increasing alkyl chain length $(n)$ from C6IP, C10IP, C14IP, to C18IP, which affected the molecular assembly structures of the organogel (OG) and liquid crystal (LC). The CnIP molecules were soluble in $\mathrm{CH}_{3} \mathrm{OH}$, $\mathrm{C}_{2} \mathrm{H}_{5} \mathrm{OH}$, acetone, and THF, whereas only slightly soluble in $\mathrm{H}_{2} \mathrm{O}, \mathrm{CH}_{3} \mathrm{CN}$, AcOEt, and toluene. Among the four CnIP derivatives, C10IP, C14IP, and C18IP can form OGs in the mixed solvent system of $\mathrm{C}_{2} \mathrm{H}_{5} \mathrm{OH}\left(\mathrm{CH}_{3} \mathrm{OH}\right)-\mathrm{H}_{2} \mathrm{O}$ (Fig. 1a) at a fixed concentration of $10 \mathrm{mM}$. Table 1 summarizes the formation of OGs in $\mathrm{C}_{2} \mathrm{H}_{5} \mathrm{OH}-\mathrm{H}_{2} \mathrm{O}$ and LCs of the CnIP derivatives. C6IP with the shortest alkyl chain did not form the OG or LC state due to insufficient hydrophobicity. The formation of an OG is closely related to the formation of $1 \mathrm{D}$ fibrous molecular assemblies and their 3D entanglements.

Therefore, the formation of 1D hydrogen-bonding tubular assembly was consistent with the formation of an OG. Among the poor solvents, $\mathrm{H}_{2} \mathrm{O}$ was essential for the formation of the $\mathrm{OG}$ of C10IP, C14IP, and C18IP, and $\mathrm{C}_{2} \mathrm{H}_{5} \mathrm{OH}$ and/or $\mathrm{CH}_{3} \mathrm{OH}$ were also needed. Although we tried to prepare OG state from a variety of solvent such as $\mathrm{THF}, \mathrm{CH}_{3} \mathrm{CN}$, AcOEt, and toluene, the addition of $\mathrm{H}_{2} \mathrm{O}$ in $\mathrm{C}_{2} \mathrm{H}_{5} \mathrm{OH}$ achieved the corresponding organogel states. The thermal stability of the OG decreased in the order of C18IP, C14IP, to C10IP, and crystalline powder coexisted with the OG in the shorter chain C10IP molecule. Therefore, crystallinity was increased by decreasing the alkyl chain length. The solubility of CnIP in $\mathrm{C}_{2} \mathrm{H}_{5} \mathrm{OH}$ decreased in the order of C6IP, C10IP, C14IP, to C18IP, and the minimum $\mathrm{H}_{2} \mathrm{O}$ content required for the formation of the respective OGs also decreased in the same order (Table 1 and Fig. S1 $\dagger$ ). The volume percentages of $\mathrm{H}_{2} \mathrm{O}$ to form stable OGs at 20, 10, 5, and $2.5 \mathrm{mM}$ solutions of C14IP in $\mathrm{C}_{2} \mathrm{H}_{5} \mathrm{OH}$ were approximately 20, 30, 40, and $50 \%$, respectively.

\section{Hydrated xerogels and unhydrated crystals}

The formation of an OG was not observed in the shortest alkyl chain C6IP derivative, whereas the OG state of C10IP was unstable at $300 \mathrm{~K}$ due to the coexistence of OG and crystalline

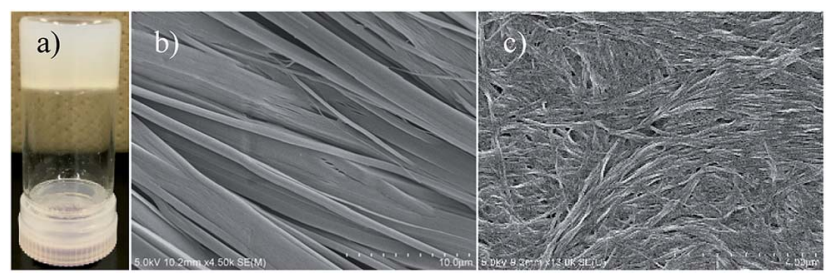

Fig. 1 Optical microscopy and SEM images of the OG, CS, and XG states. (a) Cloudy OG state of C14IP in $\mathrm{C}_{2} \mathrm{H}_{5} \mathrm{OH}-\mathrm{H}_{2} \mathrm{O}$. SEM image of (b) the CS state of unhydrated C18IP and (c) the XG state of C18IP on silicon. 
solid (CS) states. Both C14IP and C18IP derivatives can form stable and uniform OG states in $\mathrm{C}_{2} \mathrm{H}_{5} \mathrm{OH}-\mathrm{H}_{2} \mathrm{O}$ mixed solvents in the absence of CS at approximately $300 \mathrm{~K}$. Two kinds of molecular assembly states of the xerogel (XG) and CS were obtained for C14IP and C18IP (Fig. S2 $\dagger$ ) by changing the solvent system. The $\mathrm{XG}$ state was obtained by vacuum drying from the OG state in $\mathrm{C}_{2} \mathrm{H}_{5} \mathrm{OH}-\mathrm{H}_{2} \mathrm{O}$, whereas the $\mathrm{CS}$ was obtained by recrystallization from $\mathrm{CH}_{3} \mathrm{OH}, \mathrm{C}_{2} \mathrm{H}_{5} \mathrm{OH}$, or acetone in the absence of $\mathrm{H}_{2} \mathrm{O}$. The presence of $\mathrm{H}_{2} \mathrm{O}$ was a necessary condition to form both the OG and XG states. Fig. 1a shows a cloudy OG state of C14IP in $\mathrm{C}_{2} \mathrm{H}_{5} \mathrm{OH}-\mathrm{H}_{2} \mathrm{O}$ at a fixed concentration of $10 \mathrm{mM}$. The microscale morphologies of the CS and XG states of C18IP on silicon differed significantly in the SEM images. Fig. 1b and c show the SEM images of the CS and XG states of C18IP. The morphology of the CS state has a clear edge with a flat crystal surface (Fig. 1b), whereas the 3D entanglement network of each microfiber was observed in the XG state of C18IP (Fig. 1c). The latter 3D entangled microstructure was a prerequisite for the formation of the OG state. Differences in the microscale morphologies of the XG and CS are associated with microscale hydrogen-bonding interactions.

The results of the TGA of the XG and CS states of C14IP and C18IP differed to significant degree (Fig. 2a). Although the CS state exhibited high thermal stability up to $520 \mathrm{~K}$, as indicated by the absence of weight-loss, the XG state showed weight-loss at approximately $400 \mathrm{~K}$ corresponding to the desorption of $\mathrm{H}_{2} \mathrm{O}$ molecules. The magnitude of the weight-losses for the XG states of $(\mathbf{C 1 4 I P})_{6} \cdot\left(\mathrm{H}_{2} \mathrm{O}\right)_{n}$ and $(\mathbf{C 1 8 I P})_{6} \cdot\left(\mathrm{H}_{2} \mathrm{O}\right)_{n}$ at $400 \mathrm{~K}$ were $3.7-$ 7.2 and $3.3-7.3 \%$, respectively, corresponding to $5 \leq n \leq 12$ (Fig. S3 $\dagger$ ). It should be noted that the amount of $\mathrm{H}_{2} \mathrm{O}$ molecules may be influenced by environmental humidity during the vacuum drying process, accounting for the deviation in $\mathrm{H}_{2} \mathrm{O}$
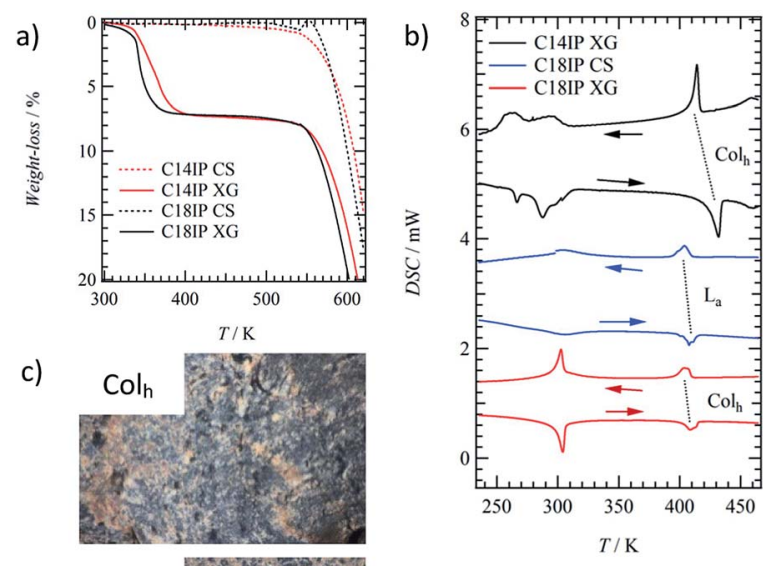

c)
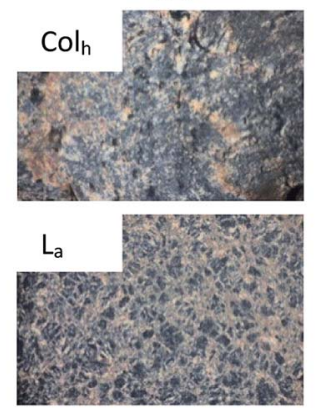

Fig. 2 Thermal properties of the $X G$ states of $(\mathrm{C} 14 \mathrm{IP})_{6} \cdot\left(\mathrm{H}_{2} \mathrm{O}\right)_{n}$ and $(\mathrm{C} 18 \mathrm{IP})_{6} \cdot\left(\mathrm{H}_{2} \mathrm{O}\right)_{n}$ and CS state of C18IP. (a) TG diagrams of the XG (solid line) and CS (dashed line) states of C14IP (red) and C18IP (black). (b) The DSC diagrams for XG of $(\mathrm{C} 14 \mathrm{IP})_{6} \cdot\left(\mathrm{H}_{2} \mathrm{O}\right)_{n},(\mathrm{C} 18 \mathrm{IP})_{6} \cdot\left(\mathrm{H}_{2} \mathrm{O}\right)_{n}$, and CS of C18IP. (c) POM images of the $\mathrm{Col}_{h}$ and $\mathrm{L}_{a}$ phases of $(\mathrm{C} 18 \mathrm{IP})_{6} \cdot\left(\mathrm{H}_{2} \mathrm{O}\right)_{n}$ and C18IP at $450 \mathrm{~K}$. content. The presence of $\mathrm{H}_{2} \mathrm{O}$ is a requirement for the formation of the OG state, where the hydrophilic $\mathrm{H}_{2} \mathrm{O}$ molecules stabilize the 1D fibrous molecular assemblies. Since the microfibrous morphology of the XG state was maintained even under vacuum during the SEM measurements, it can be concluded that the 1D fibrous molecular assemblies of C14IP and C18IP were stabilized by intermolecular hydrogen-bonding interactions.

\section{Liquid crystalline property}

The LC phases were not observed in the short alkyl chain compounds of C6IP and C10IP with direct decomposition at approximately $550 \mathrm{~K}$ (Fig. S4†). In contrast, both fluidic and birefringent behaviours of $(\mathbf{C 1 4 I P})_{6} \cdot\left(\mathrm{H}_{2} \mathrm{O}\right)_{n},(\mathbf{C 1 8 I P})_{6} \cdot\left(\mathrm{H}_{2} \mathrm{O}\right)_{n}$, and unhydrated C18IP were observed in the polarized optical microscopy (POM) images under the cross-Nicol optical arrangement by increasing the temperature to $420 \mathrm{~K}$.

The XG and CS states of C14IP and C18IP showed different phase transition behaviours in the DSC diagrams. The endothermic peaks of the XG state of $(\mathbf{C 1 4 I P})_{6} \cdot\left(\mathrm{H}_{2} \mathrm{O}\right)_{n}$ were observed at approximately 270 and $300 \mathrm{~K}$ during the heating process, which corresponded to $\mathrm{H}_{2} \mathrm{O}$ melting within the molecular assembly and were also observed in the exothermic peaks during cooling (Fig. 2b). The reversible endothermic and exothermic peaks at approximately $420 \mathrm{~K}$ corresponded to the phase transition from solid (S) to LC phase (black DSC chart in Fig. 2b). However, the phase transition from the LC to the isotopic liquid (IL) phase was not observed in the DSC of $(\mathbf{C 1 4 I P})_{6} \cdot\left(\mathrm{H}_{2} \mathrm{O}\right)_{n}$ due to decomposition at approximately $540 \mathrm{~K}$. Similar phase transition behaviour was observed in the XG state of $(\mathbf{C 1 8 I P})_{6} \cdot\left(\mathrm{H}_{2} \mathrm{O}\right)_{n}$, where a reversible S-LC phase transition peak was observed at approximately $410 \mathrm{~K}$ (red DSC chart in Fig. 2b). Although the phase transition behaviour of unhydrated C14IP was fundamentally similar to that of the hydrated $(\text { C14IP })_{6} \cdot\left(\mathrm{H}_{2} \mathrm{O}\right)_{n}$, the CS state of unhydrated C18IP exhibited a reversible S-LC phase transition peak at approximately $410 \mathrm{~K}$ (blue DSC chart in Fig. 2b). The XG and CS states of $(\mathbf{C 1 8 I P})_{6} \cdot\left(\mathrm{H}_{2} \mathrm{O}\right)_{n}$ and C18IP formed different LC phases formed from different molecular assembly structures. Fig. 2c shows the POM images of the two mesophases derived from the XG and CS states of $(\mathbf{C 1 8 I P})_{6} \cdot\left(\mathrm{H}_{2} \mathrm{O}\right)_{n}$ and C18IP at $450 \mathrm{~K}$. Although both POM textures resembled each other, a striped pattern was observed in the texture of the CS state. The molecular assembly structure within the LC phase is affected by the alkyl chain length $(n)$ of the $-\mathrm{CONHC}_{n} \mathrm{H}_{2 n+1}$ group.

To identify the molecular assembly structures of the LC phases, the XRD patterns of the two types of LC phases of $(\mathbf{C 1 4 I P})_{6} \cdot\left(\mathrm{H}_{2} \mathrm{O}\right)_{n}$ (or $\left.(\mathbf{C 1 8 I P})_{6} \cdot\left(\mathrm{H}_{2} \mathrm{O}\right)_{n}\right)$ and unhydrated C18IP were compared. Fig. 3 summarizes the XRD patterns of the LC phases of $(\mathbf{C 1 4 I P})_{6} \cdot\left(\mathrm{H}_{2} \mathrm{O}\right)_{n},(\mathbf{C 1 8 I P})_{6} \cdot\left(\mathrm{H}_{2} \mathrm{O}\right)_{n}$, and C18IP. Typical XRD patterns of $(\mathbf{C 1 4 I P})_{6} \cdot\left(\mathrm{H}_{2} \mathrm{O}\right)_{n}$ at $450 \mathrm{~K}$ were consistent the diffraction pattern of the discotic hexagonal columnar $\left(\mathrm{Col}_{\mathrm{h}}\right) \mathrm{LC}$ phase with a $d_{100}=3.62 \mathrm{~nm},{ }^{34-36}$ where the diffraction peaks at $2 \theta=2.44,4.27,4.91$, and $6.56^{\circ}$ were consistent with the index values of $d_{100}, d_{110}, d_{200}$, and $d_{210}$, respectively. In the large angle region, two broad diffraction peaks around $2 \theta=20$ and $25^{\circ}$ could be assigned to the melting state of the alkyl chains and 

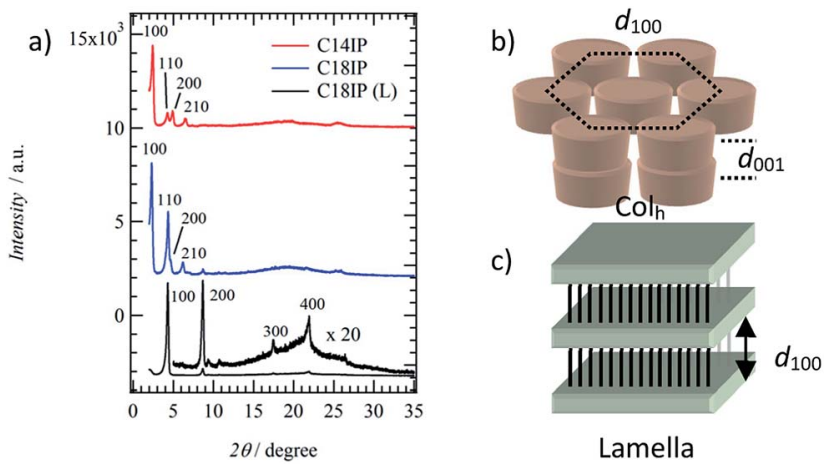

Fig. 3 Molecular assembly structures of the LC phases. (a) The XRD patterns of the $\mathrm{Col}_{n}$ phase of $(\mathrm{C} 14 \mathrm{IP})_{6} \cdot\left(\mathrm{H}_{2} \mathrm{O}\right)_{n}$ at $450 \mathrm{~K}$ (red), $(\mathrm{C} 18 \mathrm{IP})_{6} \cdot\left(\mathrm{H}_{2} \mathrm{O}\right)_{n}$ at $480 \mathrm{~K}$ (blue), and $\mathrm{L}_{a}$ phase of $\mathrm{C} 18 \mathrm{IP}$ at $460 \mathrm{~K}$ (black). Schematic packing structures and lattice periodicities of $d_{100}$ and $d_{001}$ for (b) $\mathrm{Col}_{\mathrm{h}}$ and (c) $\mathrm{L}_{\mathrm{a}}$ phases.

average interplanar distance $\left(d_{001}\right)$ along the $\pi$-stacking direction within a column. Almost identical XRD patterns were observed in LC phase of $(\mathbf{C 1 8 I P})_{6} \cdot\left(\mathrm{H}_{2} \mathrm{O}\right)_{n}$ at $480 \mathrm{~K}$, which was also consistent with the $\mathrm{Col}_{h}$ phase of $(\mathbf{C 1 4 I P})_{6} \cdot\left(\mathrm{H}_{2} \mathrm{O}\right)_{n}$. A periodicity of $d_{100}=3.84 \mathrm{~nm}$ for $(\mathbf{C 1 8 I P})_{6} \cdot\left(\mathrm{H}_{2} \mathrm{O}\right)_{n}$ was approximately $0.22 \mathrm{~nm}$ longer than that of $(\mathbf{C 1 4 I P})_{6} \cdot\left(\mathrm{H}_{2} \mathrm{O}\right)_{n}\left(d_{100}=3.62 \mathrm{~nm}\right)$. The $d_{100}$-spacing for the $\mathrm{Col}_{\mathrm{h}}$ phases of $(\mathbf{C 1 4 I P})_{6} \cdot\left(\mathrm{H}_{2} \mathrm{O}\right)_{n}$ and $(\text { C18IP })_{6} \cdot\left(\mathrm{H}_{2} \mathrm{O}\right)_{n}$ was approximately 40 and $45 \%$ smaller than the maximum molecular lengths of 5.98 and $6.98 \mathrm{~nm}$ for the (C14IP $)_{6}$ and (C18IP) ${ }_{6}$ hexamers, respectively, assuming an alltrans $-\mathrm{CONHC}_{n} \mathrm{H}_{2 n+1}$ conformation, consistent with the melting state of the alkyl chains in the $\mathrm{Col}_{\mathrm{h}}$ phase. It is worth to mention that the three-dimensional molecular assemblies of CnIP is observed even in fluid high temperature LC phase. Similar molecular assemblies of alkoxyisophthalic acid derivative in the absence of additional hydrogen-bonding $-\mathrm{CONHC}_{n} \mathrm{H}_{2 n+1}$ unit did not form the mesophase by a direct solid-isotropic liquid phase transition, ${ }^{31}$ which were completely different from the phase transition behaviors of C14IP and C18IP. This difference is clearly accounted for the role of amide-type hydrogenbonding interaction, which significantly connects each twodimension hexameric ring structures to form tubular assembly through the strong amide-type hydrogen-bonding interaction of C14IP and C18IP. As a result, the corresponding tubular molecular assemblies were stabilized to exhibit LC phase and organogel state. Interestingly, the XRD pattern of the LC phase of unhydrated C18IP was not consistent with the formation of the $\mathrm{Col}_{\mathrm{h}}$ phase. Highly ordered diffraction peaks at $2 \theta=4.31,8.68,17.45$, and $21.91^{\circ}$ at $T=460 \mathrm{~K}$ were consistent with the index values of $d_{100}, d_{200}, d_{300}$, and $d_{400}$, suggesting a layered molecular assembly structure with an interlayer spacing of $d_{001}=2.05 \mathrm{~nm}$. Therefore, the lamella $\left(\mathrm{L}_{\mathrm{a}}\right)$ type LC phase is formed during the heating of unhydrated C18IP. ${ }^{35-37}$ Infinite $\mathrm{O}-\mathrm{H} \cdots \mathrm{O}=$ hydrogen-bonding chains were assembled to form a hydrogen-bonding 2D sheet through the interchain $\mathrm{N}-\mathrm{H} \cdots \mathrm{O}=$ hydrogen-bonding interactions. The interlayer spacing of $d_{100}=2.05 \mathrm{~nm}$ in the $\mathrm{L}_{\mathrm{a}}$ phase was $0.74 \mathrm{~nm}$ shorter than the maximum length of C18IP assuming an all-trans conformation of $-\mathrm{CONHC}_{18} \mathrm{H}_{37}$.
The $\mathrm{H}_{2} \mathrm{O}$ molecules play a key role in determining the type of LC phase $\left(\mathrm{Col}_{\mathrm{h}}\right.$ and/or $\left.\mathrm{L}_{\mathrm{a}}\right)$. It should be noted that the hydrated $(\mathbf{C 1 4 I P})_{6} \cdot\left(\mathrm{H}_{2} \mathrm{O}\right)_{n}$ and $(\mathbf{C 1 8 I P})_{6} \cdot\left(\mathrm{H}_{2} \mathrm{O}\right)_{n}$ primarily formed the $\mathrm{Col}_{\mathrm{h}}$ phase and unhydrated C18IP adopted the $\mathrm{L}_{\mathrm{a}}$ phase. In the vibrational spectra (Fig. S6 and $\mathrm{S} 7 \dagger$ ), both the $-\mathrm{OH}$ and $-\mathrm{NH}$ stretching energies of $\nu_{\mathrm{O}-\mathrm{H}}^{\mathrm{a}}$ of the $-\mathrm{COOH}$ groups and of $\nu_{\mathrm{N}-\mathrm{H}}^{\mathrm{a}}$ of -CONH- for different molecular assemblies of the XG and CS states were observed at 3080 and $3302 \mathrm{~cm}^{-1}$, respectively. This suggests the formation of intermolecular $\mathrm{O}-\mathrm{H} \cdots \mathrm{O}=$ and $\mathrm{N}-\mathrm{H} \cdots \mathrm{O}=$ hydrogen-bonding interactions. In hydrated $(\mathbf{C 1 8 I P})_{6} \cdot\left(\mathrm{H}_{2} \mathrm{O}\right)_{n}$, amide-I and -II bands were observed at 1637 and $1599 \mathrm{~cm}^{-1}$, respectively, indicating the formation of intermolecular $\mathrm{N}-\mathrm{H} \cdots \mathrm{O}=$ hydrogen-bonding interactions. ${ }^{38}$ On the other hand, the amide-I and -II bands of unhydrated C18IP were observed at 1616 and $1582 \mathrm{~cm}^{-1}$, respectively. Since the formation of strong hydrogen-bonding interactions usually results in a red-shift of the vibrational band, it can be concluded that the strength of hydrogen-bonding interaction of unhydrated C18IP was stronger than that of the hydrated $(\mathbf{C 1 8 I P})_{6} \cdot\left(\mathrm{H}_{2} \mathrm{O}\right)_{n}$. This corresponds to a much denser packing structure of the former state due to its high crystallinity. There was no significant difference in the vibrational spectra of the unhydrated C14IP and hydrated $(\text { C14IP })_{6} \cdot\left(\mathrm{H}_{2} \mathrm{O}\right)_{n}$ (Fig. S7 $\dagger$ ), which formed a similar packing structure in both LC phases.

The most widely accepted molecular assembly structure of $(\mathbf{C 1 8 I P})_{6} \cdot\left(\mathrm{H}_{2} \mathrm{O}\right)_{n}$ in the $\mathrm{Col}_{\mathrm{h}}$ phase is a tubular ring-type structure, where the $\mathrm{O}-\mathrm{H} \cdots \mathrm{O}=$ hydrogen-bonding hexamer-rings of $(\mathbf{C 1 8 I P})_{6}$ are assembled to form a $\pi$-stacking tubular structure through intermolecular $\mathrm{N}-\mathrm{H} \cdots \mathrm{O}=$ hydrogen-bonding interactions along the tube. The hydrophilic pore with a diameter of $\sim 1.1 \mathrm{~nm}$ was observed on the inner side of the ring-shaped $(\mathbf{C 1 8 I P})_{6}$ hexamer, which was filled by 5-12 hydrophilic $\mathrm{H}_{2} \mathrm{O}$ molecules in the XG state. Assuming the $\pi$-stacking distance of $(\mathbf{C 1 8 I P})_{6}$ is $d_{001}=3.8 \AA$ in the $\mathrm{Col}_{\mathrm{h}}$ phase and $\mathrm{H}_{2} \mathrm{O}$ molecular volume of $\sim 30 \AA^{3}$, the hydrophilic volume available inside the pore is $361 \AA^{3}$ per $(\mathbf{C 1 8 I P})_{6}$ unit, consistent with the occupied volume of $360 \AA^{3}$ for the $12 \mathrm{H}_{2} \mathrm{O}$ molecules. The presence of $\mathrm{H}_{2} \mathrm{O}$ inside the tubular pore was also consistent with the TG and DSC analyses, formation of the $\mathrm{Col}_{\mathrm{h}}$ phase, and XRD patterns. On the other hand, the outer surface of the tubular molecular assembly was covered by hydrophobic $-\mathrm{CONHC}_{n} \mathrm{H}_{2 n+1}$ chains (Scheme 3).

Two types of LC phases $\left(\mathrm{Col}_{\mathrm{h}}\right.$ and $\left.\mathrm{L}_{\mathrm{a}}\right)$ were only observed in unhydrated C18IP. In the $\mathrm{L}_{\mathrm{a}}$ phase, each C18IP molecule formed one zig-zag $\mathrm{O}-\mathrm{H} \cdots \mathrm{O}=$ hydrogen-bonding chain as a primary assembly structure. Secondary intermolecular $\mathrm{N}-\mathrm{H} \cdots \mathrm{O}=$ hydrogen-bonding interactions generated the $2 \mathrm{D}$ molecular assembly, where the hydrophobic $-\mathrm{CONHC}_{18} \mathrm{H}_{37}$ chains were elongated along the direction normal to the hydrogen-bonding sheet to form a lamella-type molecular assembly in the absence of $\mathrm{H}_{2} \mathrm{O}$.

\section{Dielectric responses and ion inclusion}

Molecular motion in the $\mathrm{Col}_{\mathrm{h}}$ and $\mathrm{L}_{\mathrm{a}}$ phases were evaluated by the temperature- and frequency-dependent dielectric constants. The motional freedom of polar $\mathrm{H}_{2} \mathrm{O}$ molecules can be easily detected by dielectric spectroscopy. ${ }^{39}$ Fig. 4a shows the 


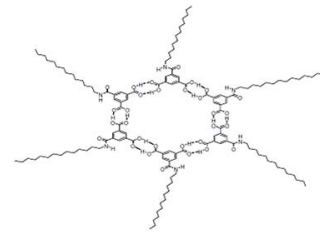

$\mathrm{O}-\mathrm{H} \bullet \bullet \mathrm{O}$ hydrogenbonding
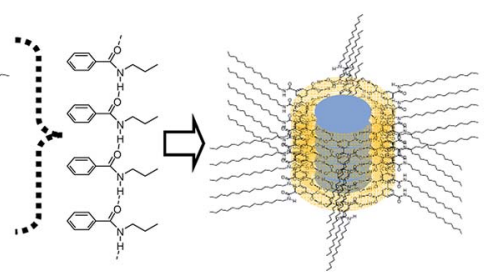

$\mathrm{N}-\mathrm{H} \cdot \cdots \cdot \mathrm{O}=$ hydrogenbonding

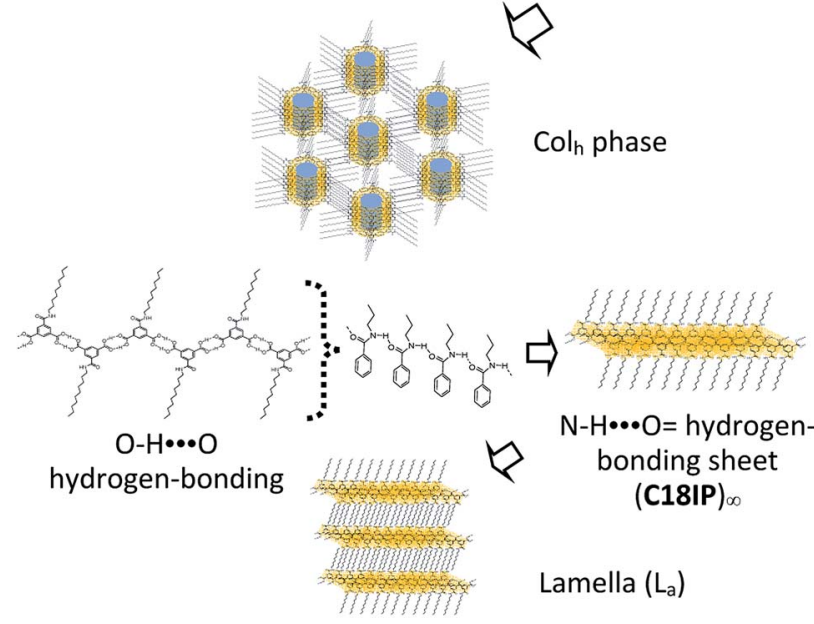

Scheme 3 Formation of the hierarchical molecular assembly structures of C18IP to form the $\mathrm{Col}_{h}$ (upper) and $\mathrm{L}_{a}$ phases (lower).

temperature- and frequency-dependent real part dielectric constant, $\varepsilon_{1}$, of hydrated $(\mathbf{C 1 8 I P})_{6} \cdot\left(\mathrm{H}_{2} \mathrm{O}\right)_{n}$ and unhydrated $(\mathbf{C 1 8 I P})_{\infty}$. The $\varepsilon_{1}-T$ plots of $(\mathbf{C 1 8 I P})_{6} \cdot\left(\mathrm{H}_{2} \mathrm{O}\right)_{n}$ showed a frequency dependent peak at $352 \mathrm{~K}$, where the low frequency $\varepsilon_{1}$ was significantly enhanced due to the slow molecular motion. Elimination of $\mathrm{H}_{2} \mathrm{O}$ in the TGA diagram was consistent with the dielectric anomaly at approximately $350 \mathrm{~K}$. In contrast, the $\varepsilon_{1}$ values of unhydrated $(\mathbf{C 1 8 I P})_{\infty}$ were temperature and frequency independent with a constant $\varepsilon_{1}$ value of $\sim 4$, completely different behavior to that of the hydrated $(\mathbf{C 1 8 I P})_{6} \cdot\left(\mathrm{H}_{2} \mathrm{O}\right)_{n}$. Therefore, the dielectric spectroscopies of hydrated $(\mathbf{C 1 8 I P})_{6} \cdot\left(\mathrm{H}_{2} \mathrm{O}\right)_{n}$ and unhydrated $(\mathbf{C 1 8 I P})_{\infty}$ confirmed the presence of $\mathrm{H}_{2} \mathrm{O}$ in the tubular assembly and its importance in the formation of different molecular assembly structures $\left(\mathrm{Col}_{\mathrm{h}}\right.$ and $\mathrm{L}_{\mathrm{a}}$ phases).
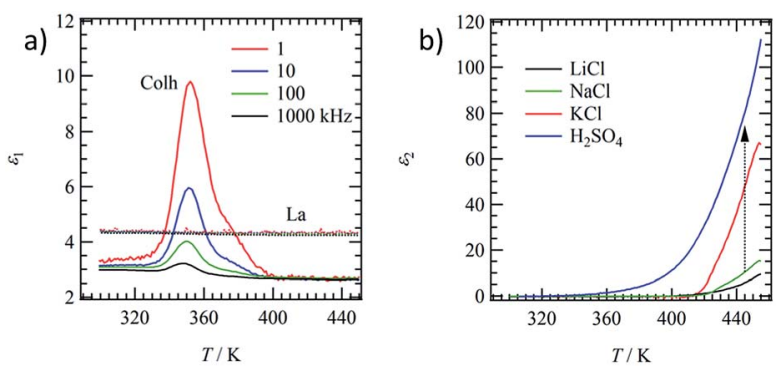

Fig. 4 Dielectric responses of CnIP. (a) Temperature and frequency dependent $\varepsilon_{1}$ of hydrated $\left(\mathrm{Col}_{h}\right)$ and unhydrated $\left(\mathrm{L}_{\mathrm{a}}\right)$ states of C18IP. (b) Temperature dependent $\varepsilon_{2}$ at $f=1 \mathrm{kHz}$ of the tubular molecular assemblies of C14IP including $\mathrm{LiCl}$ (black line), $\mathrm{NaCl}$ (green line), $\mathrm{KCl}$ (red line), and $\mathrm{H}_{2} \mathrm{SO}_{4}$ (blue line).
Hydrophilic ionic pairs such as $\mathrm{MX}=\mathrm{LiCl}, \mathrm{NaCl}, \mathrm{KCl}$, and $\mathrm{H}_{2} \mathrm{SO}_{4}$ were introduced into the inner channel of tubular molecular assembly of (C14IP) 6 . Such channel formation based on tubular molecular assembly enables to achieve the transport property for various kinds of ions along the $\pi$-stacking and amide-type hydrogen-bonding direction. ${ }^{40-43} \mathrm{~A}$ mixing ratio of MX: $(\text { C14IP })_{6}=1: 1$ can form the OG state in $\mathrm{H}_{2} \mathrm{O}-\mathrm{C}_{2} \mathrm{H}_{5} \mathrm{OH}$, which was subsequently dried under vacuum to form the XG state of $(\mathbf{C 1 4 I P})_{6} \cdot(\mathrm{MX})$. From the elemental analyses (Table $\mathrm{S} 1 \dagger)$, the formulae observed were $(\mathbf{C 1 4 I P})_{6} \cdot\left(\mathrm{LiCl}-\mathrm{H}_{2} \mathrm{O}\right)$, (C14IP) $)_{6} \cdot\left(\mathrm{NaCl}-\mathrm{H}_{2} \mathrm{O}\right),(\text { C14IP })_{6} \cdot\left(\mathrm{KCl}-\mathrm{H}_{2} \mathrm{O}\right)$, and $(\text { C14IP })_{6} \cdot\left(\mathrm{H}_{2^{-}}\right.$ $\mathrm{SO}_{4}-\mathrm{H}_{2} \mathrm{O}$ ). The formation of hexagonal columnar structure was confirmed by XRD showing typical hydrogen-bonding tubular molecular assembly structures. Therefore, the inner hydrophilic channel of the tubular molecular assembly of (C14IP) ${ }_{6}$ was filled with the corresponding hydrophilic MX species. The dielectric responses of $(\mathbf{C 1 4 I P})_{6} \cdot(\mathbf{M X})$ differ according to MX species. Fig. $4 \mathrm{~b}$ summarizes the imaginary part of the dielectric constant, $\varepsilon_{2}$, of $(\mathbf{C 1 4 I P})_{6} \cdot(\mathrm{MX})$ at a constant frequency of $f=1$ $\mathrm{kHz}$ in the second heating process. Since the $\mathrm{H}_{2} \mathrm{O}$ molecules in the second heating process were completely removed from the tubular molecular assemblies, the intrinsic dielectric responses of the unhydrated (C14IP) $)_{6}$. $(\mathrm{MX})$ were observed in the temperature dependent $\varepsilon_{2}$. The $\varepsilon_{2}$ values corresponded to the dielectricloss and/or conductive component in a parallel RC-circuit. The $\varepsilon_{2}$ values below $350 \mathrm{~K}$ were almost zero due to a lack of contribution from the conducting component. However, large $\varepsilon_{2}$ differences were observed above $400 \mathrm{~K}$ according to the MX species present in the tubular channel. The $\varepsilon_{2}$ values of (C14IP $)_{6} \cdot(\mathrm{LiCl}), \quad(\mathrm{C14IP})_{6} \cdot(\mathrm{NaCl}), \quad(\mathrm{C14IP})_{6} \cdot(\mathrm{KCl}), \quad$ and $(\mathrm{C14IP})_{6} \cdot\left(\mathrm{H}_{2} \mathrm{SO}_{4}\right)$ at $450 \mathrm{~K}$ were $7.5,13,60$, and 100 , respectively. The relatively high $\varepsilon_{2}$ value of $(\mathbf{C 1 4 I P})_{6} \cdot\left(\mathrm{H}_{2} \mathrm{SO}_{4}\right)$ originated from the protonic conductivity, and the magnitude of the $\varepsilon_{2}$ values decreased in the order of $\mathrm{H}_{2} \mathrm{SO}_{4}, \mathrm{KCl}, \mathrm{NaCl}$, to LiCl. Large MX salts have a tendency to increase the $\varepsilon_{2}$ values and the compatibility of pore diameter $(\sim 1.1 \mathrm{~nm})$ and size of the MX pair is essential in determining the $\varepsilon_{2}$ values.

\section{Conclusions}

Hydrophobic alkylamide chains $\left(-\mathrm{CONHC}_{n} \mathrm{H}_{2 n+1}\right)$ were introduced as an effective intermolecular $\mathrm{N}-\mathrm{H} \cdots \mathrm{O}=$ hydrogenbonding unit into a $\mathrm{O}-\mathrm{H} \cdots \mathrm{O}$ hydrogen-bonding isophthalic acid derivative (CnIP). The molecular aggregation behaviours of the prepared derivatives were examined by changing the alkyl chain length from $n=6,10,14$, to 18 . The $\mathrm{O}-\mathrm{H} \cdots \mathrm{O}$ hydrogenbonding interactions at the two $-\mathrm{COOH}$ sites of the isophthalic acid derivatives could form two kinds of hydrogenbonding structures; a 1D zig-zag chain and ring-shaped $(\mathbf{C n I P})_{6}$ hexamer according to the parameter $n$. Ring-shaped $\mathrm{O}-\mathrm{H} \cdots \mathrm{O}$ hydrogen-bonding hexamers were obtained in the OG state of $(\mathbf{C 1 4 I P})_{6} \cdot\left(\mathrm{H}_{2} \mathrm{O}\right)_{n}$ and $(\mathbf{C 1 8 I P})_{6} \cdot\left(\mathrm{H}_{2} \mathrm{O}\right)_{n}$, which were further assembled to a tubular molecular assembly via interhexamer $\mathrm{N}-\mathrm{H} \cdots \mathrm{O}=$ hydrogen-bonding. The formation of the OG in $\mathrm{H}_{2} \mathrm{O}-\mathrm{C}_{2} \mathrm{H}_{5} \mathrm{OH}$ was consistent with the fibrous 1D molecular assembly with a tubular structure. The hydrophilic inner pores of the 1D tubular assemblies of the XG states of 
$(\text { C14IP })_{6} \cdot\left(\mathrm{H}_{2} \mathrm{O}\right)_{n}$ and $(\text { C18IP })_{6} \cdot\left(\mathrm{H}_{2} \mathrm{O}\right)_{n}$ were occupied by $\mathrm{H}_{2} \mathrm{O}$ molecules, forming a thermotropic $\mathrm{Col}_{\mathrm{h}}$ phase upon heating. In contrast, enhanced hydrophobic interactions in C18IP formed a lamella-type molecular assembly structure in the absence of $\mathrm{H}_{2} \mathrm{O}$, where the 1D zig-zag $\mathrm{O}-\mathrm{H} \cdots \mathrm{O}$ hydrogen-bonding chains interacted through additional $\mathrm{N}-\mathrm{H} \cdots \mathrm{O}=$ hydrogen-bonding to form a 2D sheet assembly. No void space in the lamella phase was observed in the absence of $\mathrm{H}_{2} \mathrm{O}$. On the other hand, the 1D hydrophilic pore with a diameter of $1.1 \mathrm{~nm}$ in the $\mathrm{Col}_{\mathrm{h}}$ phase was suitable for $\mathrm{H}_{2} \mathrm{O}$ occupation and formation of an ion pair ( $\mathrm{MX}=\mathrm{LiCl}, \mathrm{NaCl}, \mathrm{KCl}$, and $\mathrm{H}_{2} \mathrm{SO}_{4}$ ) inclusion environment. Slight modification of the hydrophobic interactions in the $-\mathrm{CONHC}_{n} \mathrm{H}_{2 n+1}$ chains was essential for the formation of the tubular or lamella type hydrogen-bonding molecular assembly structures in simple alkylamide-substituted isophthalic acid derivatives. The hydrophilic inner channel of $(\mathbf{C n I P})_{6}$ tubular assemblies can be used for molecular and ionic transport.

\section{Conflicts of interest}

There are no conflicts to declare.

\section{Acknowledgements}

This work was supported by a Grant-in-Aid for Scientific Research on Innovative Areas " $\pi$-Figuration" (JP26102007 for T.A), KAKENHI Kiban-B (JP15H03791 for T.A.), and the "Dynamic Alliance for Open Innovation Bridging Human, Environment and Materials" from MEXT. This work is also supported by the China Scholarship Council.

\section{Notes and references}

1 The Amide Linkage, ed. A. Greenberg, C. M. Breneman and J. F. Liebman, Wiley-Interscience, NJ, 2003.

2 Peptide Solvation and H-Bonds, Advances in Protein Chemistry, ed. R. L. Baldwin and D. Baker, Elsevier Academic Press, Amsterdam, 2006, vol. 72.

3 G. R. Desiraju, T. Steiner, The Weak Hydrogen Bond, Oxford University Press, NY, 1999.

4 G. A. Jeffrey, An Introduction to Hydrogen Bonding, ed. D. G. Truhlar, Oxford University Press, NY, 1997.

5 T. Steiner, Angew. Chem., Int. Ed., 2002, 41, 48-76.

6 M. Bailey and C. J. Brown, Acta Crystallogr., 1967, 22, 387391.

7 R. Alcala and S. Martinez-Carreras, Acta Crystallogr., Sect. B: Struct. Crystallogr. Cryst. Chem., 1972, 28, 1671-1677.

8 J. L. Derissen, Acta Crystallogr., Sect. B: Struct. Crystallogr. Cryst. Chem., 1974, 30, 2764-2765.

9 D. Semmingsen, Acta Chem. Scand., 1973, 27, 3961-3972.

10 D. J. Duchamp and R. E. Marsh, Acta Crystallogr., Sect. B: Struct. Crystallogr. Cryst. Chem., 1969, 25, 5-19.

11 O. Ermer and L. Lindenberg, Helv. Chim. Acta, 1991, 74, 825877.

12 O. Ermer and A. Eling, Angew. Chem., Int. Ed., 1988, 27, 829833.
13 A. Katrusiak and M. Szafrańsk, Phys. Rev. Lett., 1999, 82, 576579.

14 M. Szafrański and A. Katrusiak, J. Phys. Chem. B, 2004, 108, 15709-15713.

15 T. Akutagawa, S. Takeda, T. Hasegawa and T. Nakamura, J. Am. Chem. Soc., 2004, 126, 291-294.

16 S. Horiuchi, Y. Tokunaga, G. Giovannetti, S. Picozzi, H. Itoh, R. Shimano, R. Kumai and Y. Tokura, Nature, 2010, 463, 789792.

17 S. Horiuchi, F. Kagawa, K. Hatahara, K. Kobayashi, R. Kumai, Y. Murakami and Y. Tokura, Nat. Commun., 2012, 3(1-6), 1308.

18 A. Sugita, K. Suzuki and S. Tasaki, Chem. Phys. Lett., 2004, 396, 131-135.

19 A. Sugita, K. Suzuki, A. Kubono and S. Tasaki, Jpn. J. Appl. Phys., 2008, 47, 1355-1358.

20 C. F. C. Fitié, W. S. C. Roelofs, M. Kemerink and R. P. Sijbesma, J. Am. Chem. Soc., 2010, 132, 6892-6893.

21 F. C. F. C. Fitié, W. S. C. Roelofs, P. C. M. M. Magusin, M. Wübbenhorst, M. Kemerink and R. P. Sijbesma, J. Phys. Chem. B, 2012, 116, 3928-3937.

22 Y. Shishido, H. Anetai, T. Takeda, N. Hoshino, S. Noro, T. Nakamura and T. Akutagawa, J. Phys. Chem. C, 2014, 118, 21204-21214.

23 H. Anetai, Y. Wada, T. Takeda, N. Hoshino, S. Yamamoto, M. Mitsuishi, T. Takenobu and T. Akutagawa, J. Phys. Chem. Lett., 2015, 6, 1813-1818.

24 H. Anetai, T. Takeda, N. Hoshino, Y. Araki, T. Wada, S. Yamamoto, M. Mitsuishi, H. Tsuchida, T. Ogoshi and T. Akutagawa, J. Phys. Chem. C, 2018, 122, 6323-6331.

25 G. Gilli, P. Gilli, The Nature of the Hydrogen Bond, Outline of a Comprehensive Hydrogen Bond Theory, Oxford Univ. Press, Oxford, 2009.

26 Supramolecular Assembly via Hydrogen Bonds I and II, ed. D. M. P. Mingos, Springer, Berlin, 2004.

27 D. González-Rodríguez and A. P. H. J. Schenning, Chem. Mater., 2011, 23, 310-325.

28 Y. Yang and C. Wang, Chem. Soc. Rev., 2009, 38, 2576-2589.

29 Y. Zhang, Y. Li and W. Liu, Adv. Funct. Mater., 2014, 25, 471480.

30 J. Yang, J. L. Marendaz, S. J. Geib and A. D. Hamilton, Tetrahedron Lett., 1994, 35, 3665-3668.

31 V. Enkelmann, S. Valiyaveettil, G. Miiessner and K. Miillen, Supramol. Sci., 1995, 2, 3-7.

32 M. Pfaadt, G. Moessner, D. Pressner, S. Valiyaveettil, C. Boeffel, K. Müllen and H. W. Spiess, J. Mater. Chem., 1995, 5, 2265-2274.

33 J. Roosma, T. Mes, P. Leclère, A. R. A. Palmans and E. W. Meijer, J. Am. Chem. Soc., 2008, 130, 1120-1121.

34 J. E. Buerkle and S. J. Rowan, Chem. Soc. Rev., 2012, 41, 60896102.

35 S. Kumar, Chemistry of Discotic Liquid Crystals, V. Percec, ed.; CRC Press, NY, 2011.

36 P. J. Collings, M. Hird, Introduction to Liquid Crystals, Chemistry and Physics, eds. G. W. Gray, J. W. Goodby and A. Fukuda, Taylor\& Francis, London, 1997. 
37 S. Chandrasekhar, Liquid Crystals, Cambridge Univ. Press, NY, 1992.

38 I. Paraschiv, M. Giesbers, B. van Lagen, F. C. Grozema, R. D. Abellon, L. D. A. Siebbeles, A. T. M. Marcelis, H. Zuilhof and E. J. R. Sudhölter, Chem. Mater., 2006, 18, 968-974.

39 K. C. Kao, Dielectric Phenomena in Solids, Elsevier, Amsterdam, 2004.
40 Y. F. Bai, K. Q. Zhao, P. Hu, B. Q. Wang and Y. Shimizu, Mol. Cryst. Liq. Cryst., 2009, 509, 60.

41 M. Yoshio, T. Mukai, H. Ohno and T. Kato, J. Am. Chem. Soc., 2004, 126, 994-995.

42 T. Kato, Science, 2002, 295, 2414-2418.

43 H. Iino, J. Hanna and D. Haarer, Phys. Rev. B, 2005, 72, 193203. 